\title{
The Telocytes in the Subepicardial Niche
}

\author{
Cristian Bogdan Iancu ${ }^{1}$, Mugurel Constantin Rusu ${ }^{1, * \mathbb{C}}$, Laurenţiu Mogoantă ${ }^{2}$, Sorin Hostiuc ${ }^{3}$ (]) \\ and Oana Daniela Toader ${ }^{4}$ \\ 1 Division of Anatomy, Faculty of Dental Medicine, “Carol Davila” University of Medicine and Pharmacy, \\ RO-050474 Bucharest, Romania; crisbo6@gmail.com \\ 2 Department of Histology, University of Medicine and Pharmacy Craiova, RO-200349 Craiova, Romania; \\ laurentiu_mogoanta@yahoo.com \\ 3 Department of Legal Medicine and Bioethics, Faculty of Dental Medicine, "Carol Davila" University of \\ Medicine and Pharmacy, RO-050474 Bucharest, Romania; soraer@gmail.com \\ 4 Department XIII of Obstetrics, Gynecology and Neonatology, "Polizu" Clinical Hospital, "Carol Davila" \\ University of Medicine and Pharmacy, RO-050474 Bucharest, Romania; oana.toader@yahoo.com \\ * Correspondence: anatomon@gmail.com; Tel.: +40-722-363-705
}

Received: 3 March 2019; Accepted: 15 April 2019; Published: 18 April 2019

\begin{abstract}
A great interest has developed over the last several years in research on interstitial Cajal-like cells (ICLCs), later renamed to telocytes (TCs). Such studies are restricted by diverse limitations. We aimed to critically review (sub)epicardial ICLCs/TCs and to bring forward supplemental immunohistochemical evidence on (sub)epicardial stromal niche inhabitants. We tested the epicardial expressions of CD117/c-kit, CD34, Cytokeratin 7 (CK7), Ki67, Platelet-Derived Growth Factor Receptor (PDGFR)- $\alpha$ and D2-40 in adult human cardiac samples. The mesothelial epicardial cells expressed D2-40, CK7, CD117/c-kit and PDGFR- $\alpha$. Subepicardial D2-40-positive lymphatic vessels and isolated D2-40-positive and CK7-positive subepicardial cells were also found. Immediate submesothelial spindle-shaped cells expressed Ki-67. Submesothelial stromal cells and endothelial tubes were PDGFR- $\alpha$-positive and CD34-positive. The expression of CD34 was pan-stromal, so a particular stromal cell type could not be distinguished. The stromal expression of CD117/c-kit was also noted. It seems that epicardial TCs could not be regarded as belonging to a unique cell type until (pre)lymphatic endothelial cells are inadequately excluded. Markers such as CD117/c-kit or CD34 seem to be improper for identifying TCs as a distinctive cell type. Care should be taken when using the immunohistochemical method and histological interpretations, as they may not produce accurate results.
\end{abstract}

Keywords: heart; pericardium; cytokeratin; c-kit; PDGFR; initial lymphatics

\section{Introduction}

Telocytes (TCs) were proposed in 2010 as being stromal cells morphologically different from other interstitial resident cells [1]. They were previously considered interstitial Cajal-like cells (ICLCs) [2-10]. Telocytes are small-sized cells residing in stem niches; they project long, slender, and moniliform prolongations, which are known as telopodes [11-14]. In recent years, TCs have been noted in almost all organs and tissues in the human body $[15,16]$. To date, no selective marker has been found for TCs [17]. The immunophenotype of TCs 'is similar to that of interstitial, endothelial, smooth muscle, mast and haematopoietic stem cells and neurons' [18]. Increasing evidence strongly suggests that, rather than being a distinctive cell type, TCs are just a cell morphology [11] of other TC-like cell types (fibroblasts, immune cells, endothelial cells, stem cells, etc.) [19-21], or a morphology resulted if thin, flat, pancake-like cells are cut and documented on two-dimensional slices [22]. Nevertheless, TCs, as a group, could simply be the result of a lack of uniformity and consensus in the terminology relating 
to CD34-positive stromal cells used by different research teams [23]. Telocytes do not appear in the Terminologia Histologica [24,25].

The cardiac lymph is drained through the initial lymphatics from the subendocardial plexus to Sappey's subepicardial plexus by intramyocardial channels; precollecting vessels drain the subepicardial plexus into collecting vessels running alongside the major coronary branches [26]. When cardiac ICLCs/TCs were documented previously, they were not distinguished from lymphatic endothelial cells [26].

Following our research on the general background of TCs, we decided to critically review and provide new immunohistochemical evidence on (sub)epicardial stromal niche inhabitants. Very few studies have attempted to characterize epicardial ICLCs/TCs in different species and by different methods [10,27-29] or to test whether or not such stromal inhabitants of a niche supplied by the overlying mesothelium belong to Sappey's subepicardial plexus. We found no previously existing evidence indicating a potential mesothelial origin of (sub)epicardial ICLCs/TCs. We therefore applied an epithelial and a lymphatic marker within a panel of antibodies that also included c-kit and CD34, commonly used markers for ICLCs/TCs [10,30-33], but also hematopoietic markers, to document potentially overlooked cells discrimination when TCs were found in the subepicardial niche.

\section{Materials and Methods}

We performed a retrospective immunohistochemical study on archived paraffin-embedded samples of adult human cardiac tissue (seven cases) resulting from donor cadavers who died of non-cardiac diseases, with age ranges from 54 to 65 years. The study was tacitly approved by the responsible authorities where the work was carried out, and it was conducted in accordance with the general principles of medical research, as stated in the Declaration of Helsinki.

The paraffin-embedded samples were processed with an automatic histoprocessor (Diapath, Martinengo, BG, Italy) with paraffin embedding. Sections were cut manually at $3 \mu \mathrm{m}$ and mounted on SuperFrost ${ }^{\circledR}$ electrostatic slides for immunohistochemistry (Thermo Scientific, Menzel-Gläser, Braunschweig, Germany). Histological evaluations used 3- $\mu$ m-thick sections stained with hematoxylin and eosin. Internal negative controls resulted when the primary antibodies were not applied on slides.

The following antibodies have been used in immunohistochemical reactions: CD117/c-kit (Y145 clone), rabbit monoclonal antibody, Biocare Medical, Concord, CA, USA; CD34 (QBEnd/10 clone), mouse monoclonal antibody, Biocare Medical, Concord, CA, USA; Cytokeratin 7/CK7 (OV-TL 12/30 clone), mouse monoclonal antibody, Biocare Medical, Concord, CA, USA; Ki67 (MIB clone), mouse monoclonal antibody, Biocare Medical, Concord, CA, USA; Platelet-Derived Growth Factor Receptor (PDGFR)- $\alpha$ (C-9 clone), mouse monoclonal antibody, Santa Cruz Biotechnology Inc. CA, USA; D2-40 Lymphatic Marker (D2-40 clone) and mouse monoclonal antibody, Biocare Medical, Concord, CA, USA.

In all cases, the tissues were deparaffinized and rehydrated prior to labelling and then treated according to the protocol to block endogenous enzymes or to unmask the antigens. For CD34, Ki67, CK7, D2-40 Lymphatic Marker and CD117/c-kit, the endogenous peroxidase was blocked using a stabilized hydrogen peroxide compound (Peroxidazed 1-Biocare Medical, Concord, CA, USA). The samples labelled with PDGFR- $\alpha$ antibody were heated at $95{ }^{\circ} \mathrm{C}$ for $5 \mathrm{~min}$ in sodium citrate buffer, $\mathrm{pH}$ 6.0, to unmask the antigen. The next steps were performed according to manufacturer's instructions. Briefly, the separate protocols are indicated below.

CD34: The samples were pretreated enzymatically using a trypsin kit (Carezyme I-Biocare Medical Concord, CA, USA). To reduce nonspecific background staining, a Background Punisher Kit (Biocare Medical, Concord, CA, USA) was used for $10 \mathrm{~min}$ at room temperature (RT). Next, the primary antibody was added at a dilution of 1:50 for one hour at RT. A two-step detection system was used: Universal Horseradish Peroxidase (HRP) Detection Kit (Biocare Medical Concord, CA, USA), employing a DAB (3,3'-diaminobenzidine) substrate for HRP-based detection.

Ki67, CK7, D2-40 Lymphatic Marker, and CD117/c-kit: Pretreatment for epitope retrieval was performed at a high temperature in a controlled environment using a Decloaking Chamber (Biocare 
Medical, Concord, CA, USA) and a retrieval solution at pH 6 (Revealer Decloaker-Biocare Medical, Concord, CA, USA); these solutions are specially formulated for superior $\mathrm{pH}$ stability at high temperatures. Blocking endogenous biotin and reducing nonspecific background was done similarly to CD34 staining. Subsequently, primary antibodies were added at a specified dilution (1:100 for Ki67, CK7, and D2-40 Lymphatic Marker and 1:200 in the case of CD117/c-kit) for half an hour to one hour at RT. Next, a secondary probe and an enzyme-labelled tertiary polymer were added consecutively at RT for $10 \mathrm{~min}$ each. These two steps belong to the MACH $4^{\mathrm{TM}}$ Universal Alkaline Phosphatase Polymer Detection Kit (Biocare Medical, Concord, CA, USA).

CD117/c-kit was treated with an enzyme-labelled secondary polymer, at RT, according to the MACH 2 Universal Alkaline Phosphatase Polymer Detection Kit (Biocare Medical, Concord, CA, USA). Finally, a HRP-based detection system employing a DAB substrate (Biocare's DAB) was used.

PDGFR- $\alpha$ : The specimens were incubated for $1 \mathrm{~h}$ in UltraCruz ${ }^{\circledR}$ Blocking Reagent (Santa Cruz Biotechnology Inc. CA, USA), followed by adding up the primary antibody at a dilution of 1:50 for $30 \mathrm{~min}$ at room temperature. After three washes with PBS, the slides were incubated for $45 \mathrm{~min}$ with biotin-conjugated secondary antibody diluted in UltraCruz ${ }^{\circledR}$ Blocking Reagent and next with avidin-biotin complex, using the A and B reagents from the ImmunoCruz ${ }^{\circledR}$ ABC Kit (Santa Cruz Biotechnology Inc. CA, USA) for another $30 \mathrm{~min}$. A peroxidase substrate and a chromogen mixture system employing hydrogen peroxide and DAB chromophore were used for detection.

The negative controls included omission of either the first- or the second-step reagent and substitution of the first-step reagent with an irrelevant isotype-matched antibody.

In all cases, the sections were counterstained with haematoxylin and rinsed with purified, deionised water.

The slides were analysed and sorted using a calibrated station for scaling numerous microphotographs. We used a Zeiss working station composed of an AxioImager M1 microscope and an AxioCam HRc camera, both integrated by AxioVision imaging software capable of image acquisition, processing, analysis, and interpretation (Carl Zeiss AG, Oberkochen, Germany).

\section{Results}

We accurately identified the epicardial histology of hematoxylin and eosin-stained slides. The single-cell mesothelial layer of epicardium covers the subepicardial stroma consisting of subepicardial fat embedding microvessels, nerves (occasionally with intrinsic solitary neurons) and microganglia, and isolated cells, both spindle-shaped and rounded.

On several samples, the epicardium appeared to be denuded of mesothelial cells. When hypertrophied mesothelial epicardial cells were present, they expressed D2-40 (Figure 1), CK7 (Figure 2), CD117/c-kit (Figure 3) and PDGFR- $\alpha$ (Figure 4). We did not observe the mesothelial expression of CD34.

Immediately beneath the mesothelial layer, lumina-presenting, thin, lymphatic vessels with circumferential dispositions were labelled with the D2-40 marker (Figure 1). Moreover, large lymphatic vessels with nuclei bulging into lumina (Figure 1) and isolated D2-40-expressing rounded cells with eccentric nuclei and small protrusions (Figure 1) were found embedded within the submesothelial fat of the samples. We noted that the endothelial cells of longitudinally cut lymphatic vessels could have a TC-like appearance, but the identification of lumina made the distinction between these cell types (Figure 1).

Rounded CK7-positive isolated subepicardial cells were identified on the slides (Figure 2). Moreover, immediate submesothelial spindle-shaped cells expressed the proliferation marker Ki-67 (Figure 2). Stromal cells and endothelial tubes in the submesothelial stroma were found expressing PDGFR- $\alpha$ (Figure 4) as well as CD34 (Figure 5). The expression of CD34 seemed pan-stromal, so no particular stromal cell type could be identified. The stromal expression of CD117/c-kit was also observed in the slides (Figure 3). 


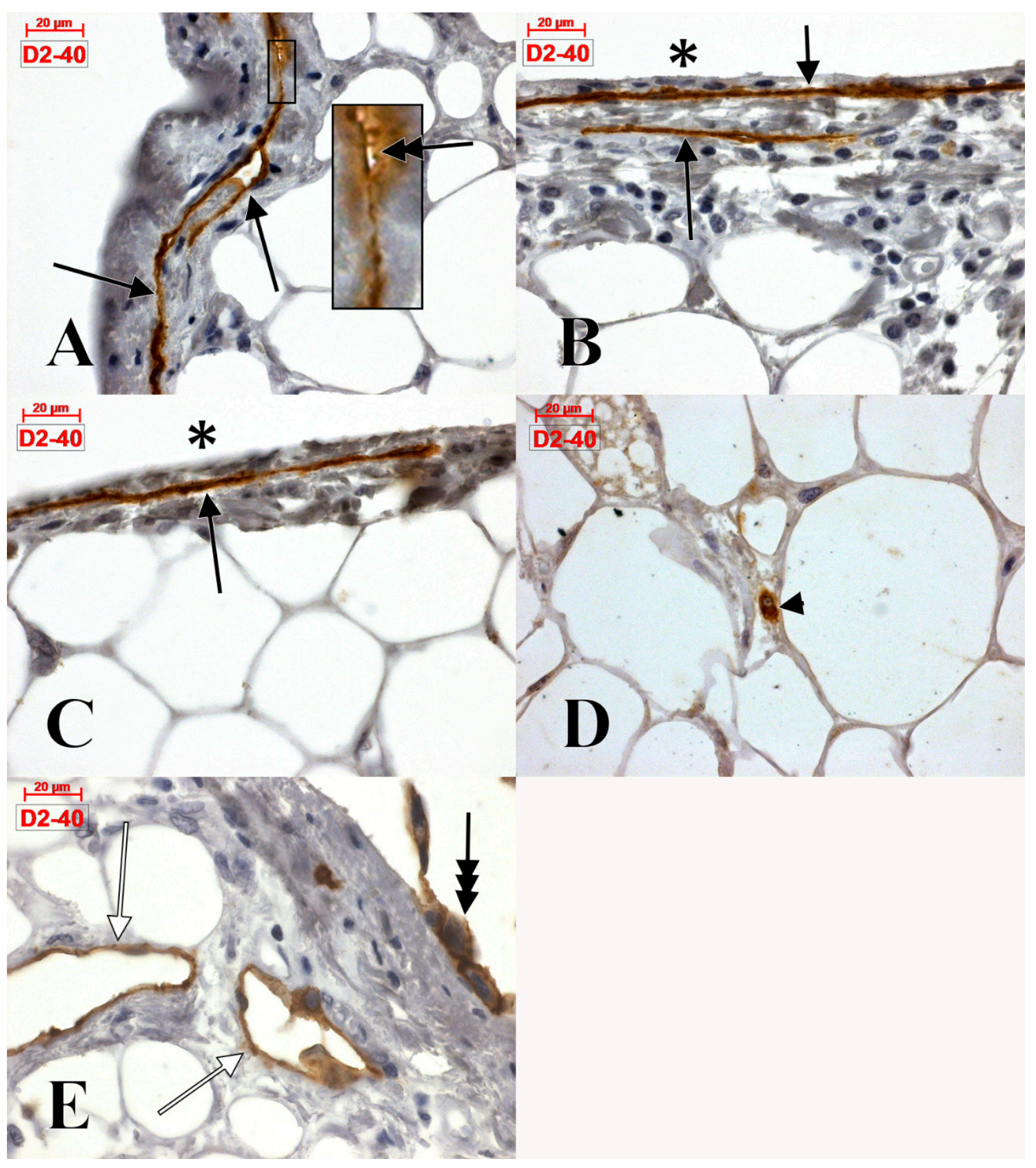

Figure 1. Human adult cardiac wall (A-D: left atrial wall, E: left atrial appendage). Epicardial and subepicardial expression of podoplanin (D2-40). Thin subepicardial lymphatics express D2-40 (A-C, arrows). When they are tangentially cut, they could be confused with telopodes (A, inset, digitally magnified) if the narrow lumen (double-headed arrow) is overlooked. The arrowhead in (D) indicates a D2-40-expressing isolated cell embedded within the subepicardial fat. Although epicardium was largely denuded of epithelium ${ }^{*}$ ) in the studied samples, there were found areas covered by D2-40 + hypertrophied mesothelial cells (E, triple-headed arrow). Large lymph collectors with intraluminally bulged endothelial cells were found embedded within the subepicardial fat (E, white arrows). 


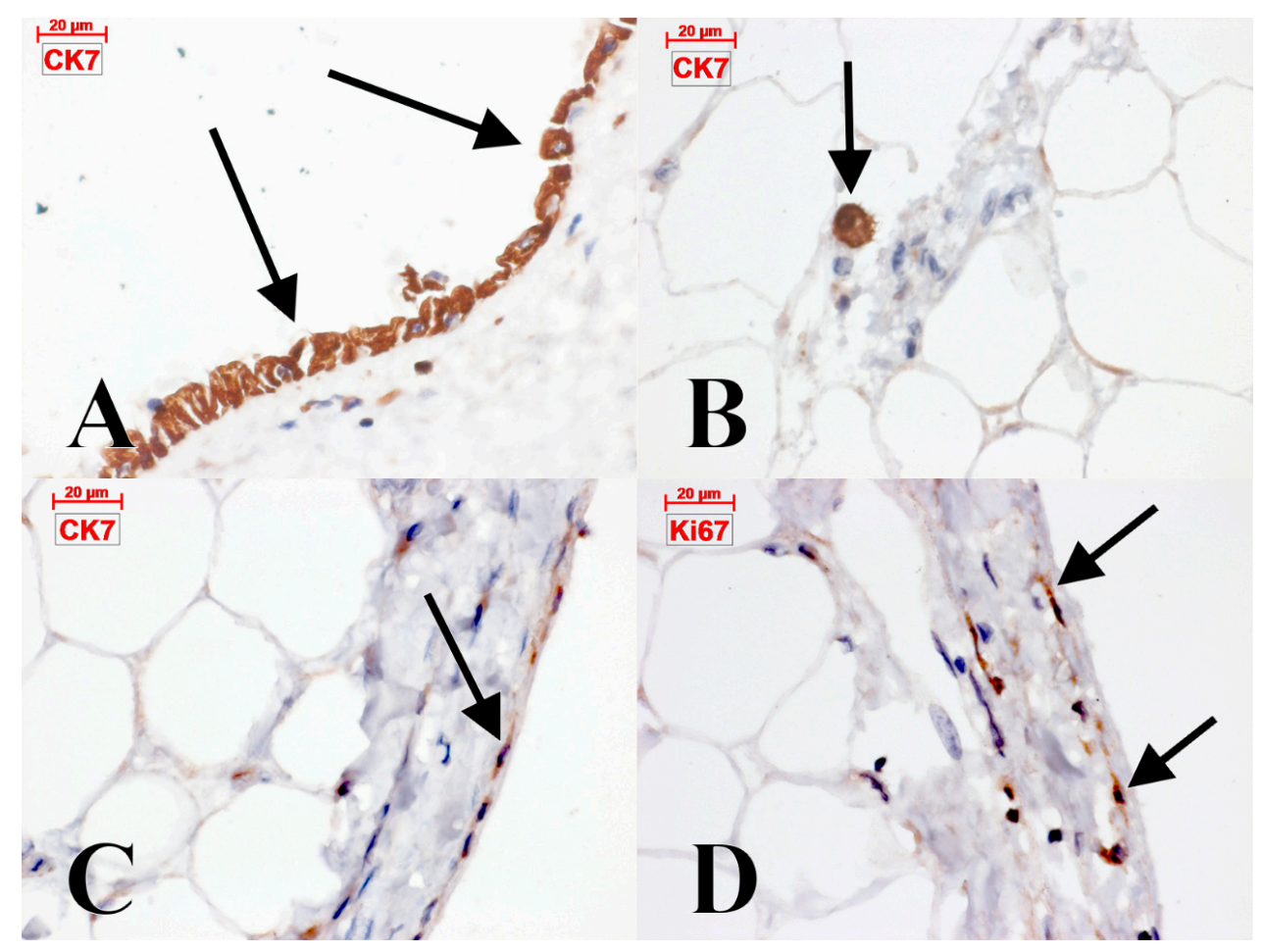

Figure 2. Human adult cardiac wall. Cytokeratin 7 is expressed in epicardial (mesothelial) cells (A, arrows), as well as in isolated subepicardial round cells (B, arrow) and in immediate subepicardial spindle-shaped slender cells (C, arrow). These last also express Ki67 (D, arrows), the proliferative marker.

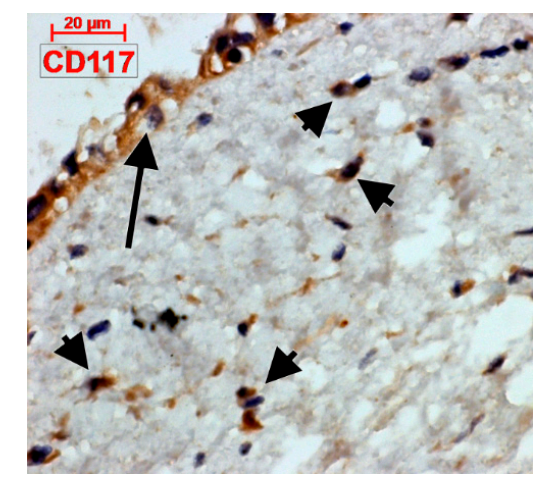

Figure 3. Human adult cardiac wall. CD117/c-kit has epicardial (mesothelial) (arrow) and subepicardial (arrowheads) expression.

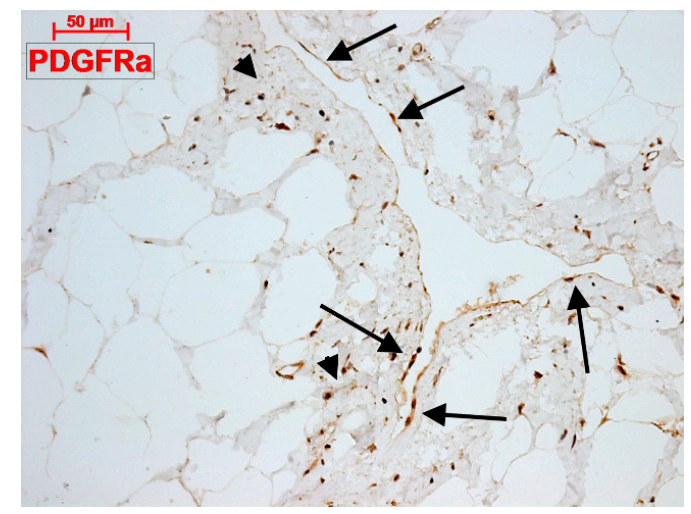

Figure 4. Human adult cardiac wall. Epicardial (mesothelial) (arrows) and subepicardial (arrowheads) expression of Platelet-Derived Growth Factor Receptor (PDGFR $\alpha$ ). 


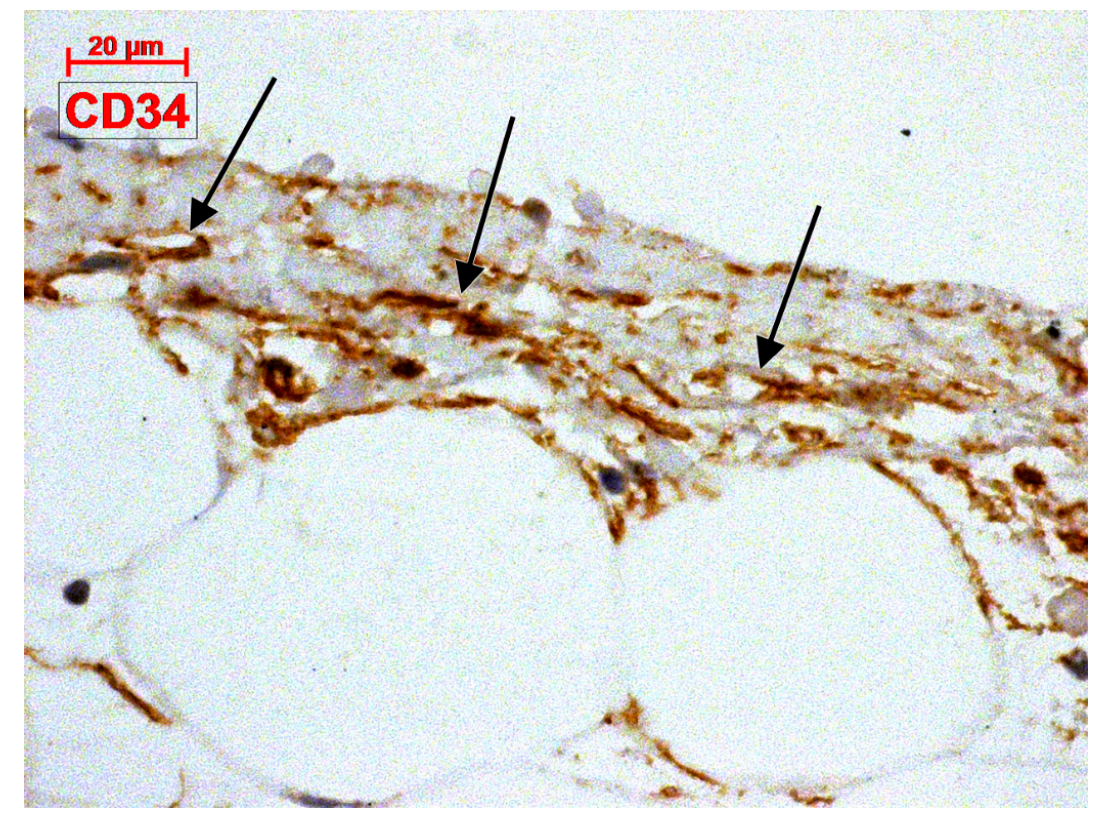

Figure 5. Human adult cardiac wall. Immediate submesothelial expression of CD34 includes nascent endothelial tubes (arrows).

\section{Discussion}

\subsection{The Epicardial Lymphatics}

The cardiac lymph is drained through the initial lymphatics from the subendocardial lymphatic plexus to Sappey's subepicardial lymphatic plexus via intramyocardial lymphatic channels; precollecting vessels from the subepicardial plexus further drain into collecting vessels neighboring the major coronary branches [26]. Here, we detected the immediate submesothelial location of Sappey's subepicardial lymphatic plexus, which consists of lymphatic vessels with circumferential dispositions. As lymphatics were overlooked in tissue samples in which cardiac ICLCs/TCs were discriminated [26], the molecular anatomy of the epicardial niche must be revisited.

\subsection{C-Kit-Positive Cardiac Cells}

The c-kit protein (CD117) is a type III tyrosine-protein kinase that recognises the stem cell factor (SCF) ligand [34]. During development, the c-kit receptor is expressed both in cardiac progenitors capable of cardiomyogenesis and in others with divergent evolution patterns [35]. This receptor-ligand interaction activates signaling pathways that are responsible for cellular proliferation, development and differentiation. We found c-kit expressed equally in epicardial mesothelial and subepicardial stromal cells, which could indicate the presence of a stem/progenitor niche and transdifferentiation processes.

The cardiac stem cells expressing c-kit have been studied extensively (see [35]). Approximately $1.1-1.8 \%$ of the myocardial cell population in humans are c-kit-positive [36,37]. Approximately half of these cells are multipotent cells, and the other half are early committed cells [38]. Interestingly, most of the detected c-kit-positive cells were found to also express two other proteins: CD45 and CD34, the pan-leukocyte and endothelial/hematopoietic progenitor markers, respectively $[39,40]$. With rare exceptions, freshly isolated c-kit-positive cells do not express myocytes ( $\alpha$-sarcomeric actin, cardiac myosin, desmin, $\alpha$-cardiac actinin and connexin 43), endothelial cells (von Willebrand factor, CD31 and vimentin), smooth muscle cells ( $\alpha$-smooth muscle actin and desmin) or fibroblast cytoplasmic proteins (fibronectin, procollagen I and vimentin) [41]. In vitro, isolated, c-kit-positive cardiac stem cells are spindle-shaped, like cardiac fibroblasts, and co-express GATA4 and NKX2.5 [36,42].

The pattern of markers displayed by c-kit-positive cells raised doubts with regards to their origin. Beltrami et al. found that endothelial progenitor cells (EPCs) express both c-kit and CD34, 
while c-kit-positive stromal cells are negative for the endothelial/hematopoietic progenitor marker CD34 [41]. They are also different from bone-marrow-derived cells, which express CD45 [41]. Interestingly, several studies demonstrated that most c-kit-positive stromal cardiac cells are mast cells that co-express CD45 [43,44], while c-kit-positive/CD45 stromal cells express mRNA of the endothelial lineage [45]. Accordingly, either c-kit-expressing TCs will not express CD34 or CD34-positive TCs are not c-kit-expressing cells. The expressions of c-kit and CD34 in cardiac interstitia are mutually exclusive and not concomitant. If they are found to be concomitant, the immunohistochemical method and its results should be checked or repeated to avoid producing inaccurate data (Figure 6).

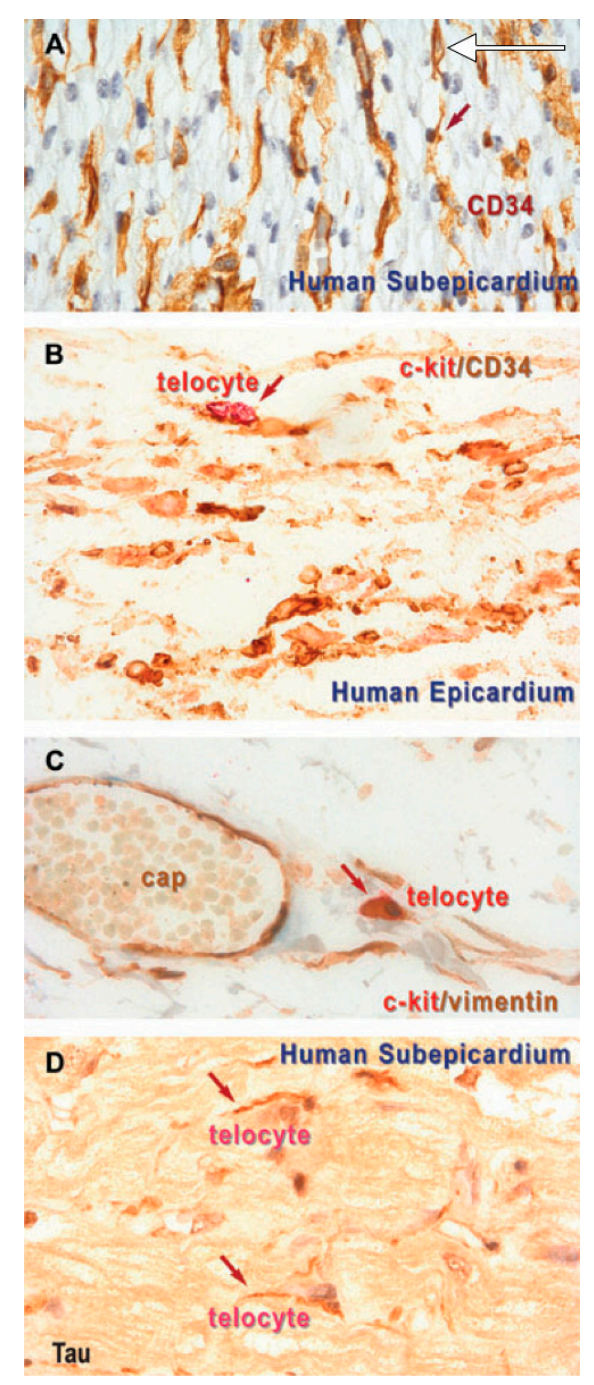

Figure 6. Reprinted with permission from John Wiley and Sons (License Number: 4562340930830) from [27]. The original legend in the *.pdf version of the article indicates "Figure 3(A) Immunostaining for CD34 (brown). CD34 positivity might be expressed by telocytes and endothelial cells. (B) Localization of double positive cells for c-Kit (red) and CD34 (brown). (C) Human epicardium, deep layer. Vimentin positivity is stronger than $c$-Kit positivity by sandwich method. (D) Cells expressing $\tau$ protein (arrows). ( $A-D)$ Original magnification, 40X". One could observe from the figure and the legend that the thin arrow added by the authors in (A) was not assigned to endothelial tubes, nor was it regarded as a telocyte, but it rather belongs to an endothelial tube (we added an additional white arrow). The cells indicated as "telocytes" in (B,C) do not display the peculiar telopodes. The expression of Tau-protein demonstrated in (D) is rather pan-tissular due to a consistent background staining. The double-labelling result in (B) indicating a c-kit+/CD34+ phenotype of telocytes (TCs) is highly speculative due to an invalid immunohistochemical method that determined the pan-labelling of the slide. 


\subsection{What Are (Sub)epicardial TCs?}

Stem cells can originate from the epithelial-mesenchymal transformation (EMT) of epicardial mesothelial cells (EMCs) in the adult human heart [46,47]. Epicardium-derived cells (EPDCs) are known to express CD117/c-kit [46], which matches with our results. Immunofluorescence of the ICLCs found subepicardial TCs immediately beneath the CD34-positive epicardial mesothelium, which were either CD34-positive/c-kit-positive or purely c-kit-positive [10]. It appears that subepicardial ICLCs/TCs are EPDCs. This is reinforced by our discovery of proliferative immediate submesothelial Ki-67-positive spindle-shaped cells. Such submesothelial ICLCs were further documented through transmission electron microscopy (TEM) by the same research group; beneath them, 'isolated smooth muscle cells' were found [29]. In that study [29], subepicardial ICLCs were speculated through TEM without the aid of any antibodies. Further studies of the subepicardial niche were performed by Popescu et al., who reported an enlarged panel of markers useful for the identification of subepicardial TCs, such as vimentin, S100 protein, tau protein, CD57 and nestin [27]. This last antibody was listed in the report's Materials and Methods section but was not documented in the Results section of that article [27]. A polyclonal antibody was then used against CD117/c-kit [27], but that immunohistochemical method included an antigen retrieval stage (though this procedure may produce nonspecific staining results) [48]. Completely and nonspecifically stained slides were then used to sample the findings on the subepicardial TCs (Figure 6), so the respective evidence could not convince. This is demonstrative of the highly subjective manner in which TCs were assigned molecular phenotypes in the past. As we discussed previously, a lack of evidence for telepodes does not exclude the possibility of a TC morphology being present [20]. Notably, the possible expression of tau protein in TCs was speculated (Figure 6) but not discussed further in that study [27], although the presence of this protein would have indicated the presence of microtubular content in TCs. This, in turn, may have been perplexing; when this research team identified the ultrastructural anatomy of TCs [1], microtubules were not listed.

In another study, epicardial ICLCs were found to be positive for c-kit and/or CD34, or they co-expressed c-kit and vimentin [10]. In a subsequent study, epicardial TCs were found to co-express either c-kit and CD34 or c-kit and vimentin [27]. In both these studies, Popescu et al. did not examine the epicardial expressions of lymphatic markers, mast cell markers or CD45. The expression of c-kit combined with the expressions of well-known endothelial markers, such as CD34 and vimentin, could not exclude TCs from the possibility of being of the endothelial lineage. It was suggested to use CD31 to discriminate the endothelial cells from TCs [49]. We also noted the striking histological resemblance of c-kit-positive epicardial 'telocytes' (Figure 2B in [27]) to c-kit-positive mast cells (Figure 1D in [50]). Both appear as large and degranulating cells. All these observations support recent and consistent evidence for TCs' failure to be categorized as a distinctive cell type $[11,24,26]$.

\subsection{The Epicardial and Subepicardial Expression of Podoplanin}

Although in the central nervous system (CNS) and thymus, endothelial cells and pericytes result from ectoderm-derived neural crest cells, they are mesoderm- and mesothelium-derived in coelomic organs [51]. This supports the (re)activated mechanism of mesothelial-to-endothelial/pericitary transformation in epicardial cells, which is actually an epithelial-mesenchymal transformation (EMT), ensuring that either subepicardial vasculogenesis or subepicardial lymphvasculogenesis occurs. This reasonably correlates with our evidence of podoplanin-expressing mesothelial cells and submesothelial lymphatics and isolated cells. We also found PDGFR- $\alpha$-expressing epicardial mesothelial cells; this is normal, as signaling through both PDGFRs, $\alpha$ and $\beta$, is needed for epicardial EMT and the formation of EPDCs [52]. In these regards, testing the PDGFR expression in mesothelial cells would support a potential of EMT in the samples studied. PDGFR- $\alpha$ is crucial in the differentiation of cardiac fibroblasts from EPDCs [53], so a PDGFR- $\alpha$-positive subepicardial stroma would clearly indicate a subepicardium with reparatory potential, regardless of whether the respective stromal cells do or do not have telopodes. A strong expression of PDGFR- $\alpha$ in human adult cardiac tissue was demonstrated in the interstitial cells of the subepicardium, myocardium, endocardium, coronary smooth muscle and endothelial 
cells, as we also found, and cardiomyocytes express this marker [13,54]. PDGFR- $\alpha$ was not tested in previous studies on epicardial and subepicardial TCs, although Creţoiu and Popescu indicated that 'CD34/PDGFR[-] $\alpha$ double immunohistochemistry can orientate the diagnosis' [55]. This double expression was used for TC identification in other normal and pathological non-cardiac tissues [56-60]. Cardiac TCs were indicated to have a CD34-positive/PDGFR- $\alpha$-positive phenotype [61], but this resulted in cell cultures that did not use any sorting molecules; cells were sorted solely based on morphological criteria. Moreover, the rodent hearts analysed 'were minced into $1 \mathrm{~mm}^{3}$ pieces and incubated on an orbital shaker' [61], which could not permit the discrimination of epicardium-specific cells from other cell populations in those cardiac samples.

Podoplanin (or GP36, E11 antigen, oncofetal antigens M2A and T1A-2, aggrus) is a mucin-type transmembrane glycoprotein first identified as podoplanin in podocytes [62-64] but as the E11 antigen in osteoblasts and osteocytes $[65,66]$. Podoplanin is homologous to the oncofetal antigen M2A, which is recognized by the D2-40 antibody [67]. Lymphatic endothelial cells express high levels of podoplanin [68]. Podoplanin has homologues in humans, mice, rats, dogs and hamsters and is relatively well-conserved between species [68]. Podoplanin is a cell morphological regulator [67] and is required for normal heart development, specifically for EMT in epicardium-derived cells [68], and our evidence reasonably suggests that this role of podoplanin also exists in adult tissues. During development, podoplanin is expressed in the epithelial lining of the coelomic wall of the pericardio-peritoneal canal and in the cells lining the pleural and pericardial cavities [66]. Podoplanin is expressed in epithelial and mesothelial cells, such as those in the intestinal epithelium, alveolar type I cells, podocytes, the mesothelium of the visceral peritoneum [66] and, as we demonstrated, in epicardial mesothelial cells.

Several markers could be used to identify lymphatic endothelial cells on slides, such as CD31 (the pan-endothelial marker), podoplanin (D2-40), Vascular Endothelial Growth Factor Receptor-3 (VEGFR-3), Lymphatic Vascular Endothelial Hyaluronan Receptor-1 (LYVE-1) and Prospero related homeobox1 (PROX1) [69]. Therefore, further co-staining experiments could be helpful in better assessing the lymphatic anatomy of subepicardium. CD31 was noted as useful in discriminating between TCs and endothelial cells, as both are known to express CD34 [70]. It was recently demonstrated that pre-lymphatic interstitial spaces are lined by TC-like endothelial cells that express vimentin, CD34 and D2-40 but do not express other lymphatic markers, such as CD31, ERG (avian v-ets erythroblastosis virus E26 oncogene homolog) or LYVE-1 [71]. Therefore, neither CD31 nor lymphatic markers other than podoplanin/D2-40 could disprove the relationship between TCs and the lymph drainage pathway.

The processes of EMT allow epithelial cells to become mobile mesenchymal cells after the epithelial adherens junctions loosen through E-cadherin loss [66]. Podoplanin can be presented as an inhibitor of E-cadherin, thus stimulating the EMT process, which involves the epicardium in myocardial differentiation [66]. Therefore, expression of D2-40 in mesothelial cells, such as we found, could be indicative of the EMT potential of D2-40-positive mesothelial cells. Such transdifferentiations could support the potential for cardiac lymphatic vasculature to increase in major cardiac pathological changes, such as acute and chronic ischaemia, progressive atherosclerosis, myocarditis and hypertrophy [72].

\subsection{Processes of Epicardial Transdifferentiation}

The transition of a cell from an epithelial to a mesenchymal phenotype, or EMT, has been shown to play critical roles in several physiological and pathological contexts, from embryogenesis to fibrosis and cancer progression [73]. The postnatal mammalian epicardium is a dormant single-cell layer [74]. After an injury, the adult epicardium is activated, which involves the induction of a developmental gene program, EMT and migration [75]. Several genes are involved in epicardial activation, including WT1 (Wilms' tumour 1), TBX18 and RALDH2 [74]. Human EPDCs closely resemble submesothelial fibroblasts and express cardiac marker genes, such as GATA4 and cardiac troponin T [76]. EPDCs display intense $\beta$-catenin staining, which supports their epithelial nature [76]. The reactivation of the epicardium occurs in ischaemia, with the re-expression of developmental genes and renewed EMT [77]. 
We have brought forward evidence of CK7 expression in EMCs as well as in isolated subepicardial stromal cells that could be viewed as EPDCs. To our knowledge, the CK7 marker has not been tested previously on human cardiac samples. CK7 should therefore be included in the list of known markers of EPDCs, such as $\beta$-catenin, CD44, CD46, CD90, CD105, HLA-ABC [76] and WT1 [78]. The expression of CD117/c-kit was also associated with EPDCs [46]. We also found c-kit expressed in mesothelial cells, which could indicate that the stem/progenitor phenotype of future EPDCs could be acquired prior to the stromal migration of the epithelial cells. During human cardiogenesis, ventricular and atrial epicardia exhibit different pan-cytokeratin expression patterns and cell arrangements; atrial epicardial cells are distributed in a stochastic fashion on the surface with a diffuse cytokeratin expression throughout the cytoplasm, whereas ventricular epicardial cells exhibit a spindle-cell morphology and preferential alignment, being orientated side-by-side with strong cytokeratin staining outlining the cell membrane and cytoskeletal filaments [79]. Polyclonal anti-keratin antibodies were used to stain the mesothelial and mesenchymal cells of the proepicardium, as well as epicardium, in quail embryos [80,81], and not in human samples.

Adult EPDCs can form tube-like structures [75]. Tangentially cut tube-like structures, if tangentially cut, could appear on slides or grids as TC-like cells [82]. We found such D2-40-expressing tubes immediately beneath the podoplanin-expressing epicardial mesothelium, which strongly suggests that subepicardial lymphatics could acquire an epicardial-based support for their maintenance.

In a static two-dimensional TEM study of epicardial ICLCs, Gherghiceanu and Popescu observed that mesenchymal cells, 'guided by ICLCs, were found migrating from [the] sub-epicardial area in the mesothelial layer'; that is, they were 'migrating under the basal lamina of the epicardial mesothelial cell' [29]. The authors also speculated that 'epithelial-mesenchymal transition is not a common process involved in cardiac regeneration in vivo' [29]. That concept inspired us to document the processes of mesenchymal-epithelial transition (MET) mentioned by this TEM study.

TGF $\beta$-induced EMT could be reversed through inhibition of the Smad2 signaling pathway [83]. Serum-free culture media, as well as TGF $\beta$ receptor inhibitors, notch receptor inhibitors or Rho-associated coiled-coil protein kinase (ROCK) inhibitors could inhibit EMT in differentiated epithelial cells or could induce MET in dedifferentiated epithelial cells [84].

The metanephric mesenchyme suffers an epithelial transformation regulated by WNT4 [85]. During this transformation, the WNT4 signal can be replaced by other members of the WNT gene family, including WNT1, WNT3A, WNT7A and WNT7B [86]. WNT proteins are also involved in cardiac development and differentiation [87]. The classic canonical WNT signaling pathway involves $\beta$-catenin [87]. The epicardial retinoic $X$ receptor $\alpha$ is required for the EMT of epicardial cells, as the loss of that receptor results in damaged myocardial growth and coronary artery formation. WNT9B is downstream of the epicardial retinoic $X$ receptor $\alpha$, which in turn regulates FGF $\beta$ expression in the myocardium $[87,88]$. The in vitro EMT of human adult epicardial cells is regulated by TGF $\beta$-signaling and WT-1 [78]. Gherghiceanu and Popescu's TEM discovery of isolated smooth muscle cells in the subepicardial space was appreciated as 'quite unique' and able to explain why EPDCs generate smooth muscle cells in cultures [29]. This is not a novelty, as both human and rat epicardial cells could be transdifferentiated to smooth muscle cells [76], and TGF $\beta$ stimulates the process of transdifferentiation [89].

Interestingly, during cardiac development, the atrial and ventricular epicardia behave differently under ex vivo conditions: only the ventricular EPDCs spontaneously undergo EMT (that is, growing with a spindle-like morphology and diminishing the expressions of WT-1, GATA5, TBX18 and TCF21) [79].

\section{Conclusions}

As the epicardium may undergo several different transdifferentiation processes, it is hazardous to designate intermediate cell stages as specific cell types. Epicardial ICLCs/TCs cannot be regarded as a particular cell type as (pre)lymphatic endothelial cells are inadequately excluded. Markers 
such as CD117/c-kit and CD34 seem to be unsuitable for identifying TCs as a distinctive cell type. The identification of TCs on two-dimensional slides should be regarded with caution, and researchers using the immunohistochemical method and related protocols should be careful to avoid gathering and promoting nonspecific or inaccurate results.

Author Contributions: Conceptualization, C.B.I. and M.C.R.; methodology, L.M.; software, S.H. and M.C.R.; validation, M.C.R., S.H. and L.M.; investigation, C.B.I., O.D.T.; writing-original draft preparation, C.B.I.; writing - review and editing, M.C.R. and S.H.

Funding: This research received no external funding.

Conflicts of Interest: The authors declare no conflict of interest.

\section{References}

1. Popescu, L.M.; Faussone-Pellegrini, M.S. TELOCYTES-A case of serendipity: The winding way from Interstitial Cells of Cajal (ICC), via Interstitial Cajal-Like Cells (ICLC) to TELOCYTES. J. Cell. Mol. Med. 2010, 14, 729-740. [CrossRef] [PubMed]

2. Ciontea, S.M.; Radu, E.; Regalia, T.; Ceafalan, L.; Cretoiu, D.; Gherghiceanu, M.; Braga, R.I.; Malincenco, M.; Zagrean, L.; Hinescu, M.E.; et al. C-kit immunopositive interstitial cells (Cajal-type) in human myometrium. J. Cell. Mol. Med. 2005, 9, 407-420. [CrossRef] [PubMed]

3. Cretoiu, D.; Ciontea, S.M.; Popescu, L.M.; Ceafalan, L.; Ardeleanu, C. Interstitial Cajal-like cells (ICLC) as steroid hormone sensors in human myometrium: Immunocytochemical approach. J. Cell. Mol. Med. 2006, 10, 789-795. [CrossRef]

4. Gherghiceanu, M.; Hinescu, M.E.; Andrei, F.; Mandache, E.; Macarie, C.E.; Faussone-Pellegrini, M.S.; Popescu, L.M. Interstitial Cajal-like cells (ICLC) in myocardial sleeves of human pulmonary veins. J. Cell. Mol. Med. 2008, 12, 1777-1781. [CrossRef] [PubMed]

5. Gherghiceanu, M.; Hinescu, M.E.; Popescu, L.M. Myocardial interstitial Cajal-like cells (ICLC) in caveolin-1 KO mice. J. Cell. Mol. Med. 2009, 13, 202-206. [CrossRef]

6. Hinescu, M.E.; Gherghiceanu, M.; Mandache, E.; Ciontea, S.M.; Popescu, L.M. Interstitial Cajal-like cells (ICLC) in atrial myocardium: Ultrastructural and immunohistochemical characterization. J. Cell. Mol. Med. 2006, 10, 243-257. [CrossRef]

7. Hinescu, M.E.; Popescu, L.M. Interstitial Cajal-like cells (ICLC) in human atrial myocardium. J. Cell. Mol. Med. 2005, 9, 972-975. [CrossRef]

8. Kostin, S.; Popescu, L.M. A distinct type of cell in myocardium: Interstitial Cajal-like cells (ICLCs). J. Cell. Mol. Med. 2009, 13, 295-308. [CrossRef]

9. Pieri, L.; Vannucchi, M.G.; Faussone-Pellegrini, M.S. Histochemical and ultrastructural characteristics of an interstitial cell type different from ICC and resident in the muscle coat of human gut. J. Cell. Mol. Med. 2008, 12, 1944-1955. [CrossRef]

10. Suciu, L.; Popescu, L.M.; Regalia, T.; Ardelean, A.; Manole, C.G. Epicardium: Interstitial Cajal-like cells (ICLC) highlighted by immunofluorescence. J. Cell. Mol. Med. 2009, 13, 771-777. [CrossRef]

11. Iancu, C.B.; Rusu, M.C.; Mogoanta, L.; Hostiuc, S.; Grigoriu, M. Myocardial Telocyte-Like Cells: A Review Including New Evidence. Cells Tissues Organs 2019. [CrossRef]

12. Rusu, M.C.; Folescu, R.; Manoiu, V.S.; Didilescu, A.C. Suburothelial interstitial cells. Cells Tissues Organs 2014, 199, 59-72. [CrossRef]

13. Rusu, M.C.; Hostiuc, S.; Vrapciu, A.D.; Mogoanta, L.; Manoiu, V.S.; Grigoriu, F. Subsets of telocytes: Myocardial telocytes. Ann. Anat. 2017, 209, 37-44. [CrossRef]

14. Grigoriu, F.; Hostiuc, S.; Vrapciu, A.D.; Rusu, M.C. Subsets of telocytes: The progenitor cells in the human endocardial niche. Rom. J. Morphol. Embryol. 2016, 57, 767-774.

15. Varga, I.; Polak, S.; Kyselovic, J.; Kachlik, D.; Danisovic, L.; Klein, M. Recently Discovered Interstitial Cell Population of Telocytes: Distinguishing Facts from Fiction Regarding Their Role in the Pathogenesis of Diverse Diseases Called “Telocytopathies". Medicina 2019, 55, 56. [CrossRef]

16. Dobra, M.A.; Vrapciu, A.D.; Pop, F.; Petre, N.; Rusu, M.C. The molecular phenotypes of ureteral telocytes are layer-specific. Acta Histochem. 2017. [CrossRef] 
17. Vannucchi, M.G.; Traini, C. The telocytes/myofibroblasts 3-D network forms a stretch receptor in the human bladder mucosa. Is this structure involved in the detrusor overactive diseases? Ann. Anat. 2018, 218, 118-123. [CrossRef] [PubMed]

18. Mitrofanova, L.B.; Gorshkov, A.N.; Konovalov, P.V.; Krylova, J.S. Telocytes in the human sinoatrial node. J. Cell. Mol. Med. 2017. [CrossRef] [PubMed]

19. Rusu, M.C.; Hostiuc, S. Telocytes and telocytes-like cells. Past, present, and above all future. Ann. Anat. 2019. [CrossRef]

20. Petrea, C.E.; Craitoiu, S.; Vrapciu, A.D.; Manoiu, V.S.; Rusu, M.C. The telopode- and filopode-projecting heterogeneous stromal cells of the human sclera niche. Ann. Anat. 2018, 218, 129-140. [CrossRef] [PubMed]

21. Petrea, C.E.; Rusu, M.C.; Manoiu, V.S.; Vrapciu, A.D. Telocyte-Like Cells Containing Weibel-Palade Bodies in Rat Lamina Fusca. Ann. Anat. 2018, 218, 88-94. [CrossRef] [PubMed]

22. Neuhaus, J.; Schroppel, B.; Dass, M.; Zimmermann, H.; Wolburg, H.; Fallier-Becker, P.; Gevaert, T.; Burkhardt, C.J.; Do, H.M.; Stolzenburg, J.U. 3D-electron microscopic characterization of interstitial cells in the human bladder upper lamina propria. Neurourol. Urodyn. 2018, 37, 89-98. [CrossRef]

23. Diaz-Flores, L.; Gutierrez, R.; Garcia, M.P.; Saez, F.J.; Diaz-Flores, L., Jr.; Valladares, F.; Madrid, J.F. CD34+ stromal cells/fibroblasts/fibrocytes/telocytes as a tissue reserve and a principal source of mesenchymal cells. Location, morphology, function and role in pathology. Histol. Histopathol. 2014, 29, 831-870. [CrossRef]

24. Varga, I.; Kyselovič, J.; Danišovič, L'.; Gálfiová, P.; Kachlík, D.; Polák, Š.; Klein, M. Recently discovered interstitial cells termed telocytes: Distinguishing cell-biological and histological facts from fictions. Biologia 2018. [CrossRef]

25. Varga, I.; Danisovic, L.; Kyselovic, J.; Gazova, A.; Musil, P.; Miko, M.; Polak, S. The functional morphology and role of cardiac telocytes in myocardium regeneration. Can. J. Physiol. Pharmacol. 2016. [CrossRef]

26. Rusu, M.C.; Hostiuc, S. Critical review: Cardiac telocytes vs cardiac lymphatic endothelial cells. Ann. Anat. 2019, 222, 40-54. [CrossRef] [PubMed]

27. Popescu, L.M.; Manole, C.G.; Gherghiceanu, M.; Ardelean, A.; Nicolescu, M.I.; Hinescu, M.E.; Kostin, S. Telocytes in human epicardium. J. Cell. Mol. Med. 2010, 14, 2085-2093. [CrossRef] [PubMed]

28. Popescu, L.M.; Gherghiceanu, M.; Manole, C.G.; Faussone-Pellegrini, M.S. Cardiac renewing: Interstitial Cajal-like cells nurse cardiomyocyte progenitors in epicardial stem cell niches. J. Cell. Mol. Med. 2009, 13, 866-886. [CrossRef]

29. Gherghiceanu, M.; Popescu, L.M. Human epicardium: Ultrastructural ancestry of mesothelium and mesenchymal cells. J. Cell. Mol. Med. 2009, 13, 2949-2951. [CrossRef]

30. Rusu, M.C.; Pop, F.; Hostiuc, S.; Dermengiu, D.; Lala, A.I.; Ion, D.A.; Manoiu, V.S.; Mirancea, N. The human trigeminal ganglion: C-kit positive neurons and interstitial cells. Ann. Anat. 2011, 193, 403-411. [CrossRef]

31. Suciu, L.; Popescu, L.M.; Gherghiceanu, M.; Regalia, T.; Nicolescu, M.I.; Hinescu, M.E.; Faussone-Pellegrini, M.S. Telocytes in human term placenta: Morphology and phenotype. Cells Tissues Organs 2010, 192, 325-339. [CrossRef]

32. Chang, Y.; Li, C.; Lu, Z.; Li, H.; Guo, Z. Multiple immunophenotypes of cardiac telocytes. Exp. Cell Res. 2015, 338, 239-244. [CrossRef]

33. Petre, N.; Rusu, M.C.; Pop, F.; Jianu, A.M. Telocytes of the mammary gland stroma. Folia Morphol. 2016, 75, 224-231. [CrossRef]

34. Iancu, C.B.; Iancu, D.; Rentea, I.; Hostiuc, S.; Dermengiu, D.; Rusu, M.C. Molecular signatures of cardiac stem cells. Rom. J. Morphol. Embryol. 2015, 56, 1255-1262.

35. Keith, M.C.; Bolli, R. "String Theory" of c-kitpos Cardiac Cells: A New Paradigm Regarding the Nature of These Cells That May Reconcile Apparently Discrepant Results. Circ. Res. 2015, 116, 1216-1230. [CrossRef]

36. Bearzi, C.; Rota, M.; Hosoda, T.; Tillmanns, J.; Nascimbene, A.; De Angelis, A.; Yasuzawa-Amano, S.; Trofimova, I.; Siggins, R.W.; Lecapitaine, N.; et al. Human cardiac stem cells. Proc. Natl. Acad. Sci. USA 2007, 104, 14068-14073. [CrossRef]

37. Choi, S.H.; Jung, S.Y.; Asahara, T.; Suh, W.; Kwon, S.-M.; Baek, S.H. Direct comparison of distinct cardiomyogenic induction methodologies in human cardiac-derived c-kit positive progenitor cells. Tissue Eng. Regen. Med. 2012, 9, 311-319. [CrossRef]

38. Bearzi, C.; Cascapera, S.; Nascimbene, A.; Casarsa, C.; Rastaldo, R.; Hosoda, T.; De Angelis, A.; Rota, M.; Quaini, F.; Urbanek, K.; et al. Late-Breaking Basic Science Abstracts. Late Breaking Developments in Stem Cell Biology and Cardiac Growth Regulation. Circulation 2005, 111, 1720-1724. 
39. Ye, J.; Boyle, A.; Shih, H.; Sievers, R.E.; Zhang, Y.; Prasad, M.; Su, H.; Zhou, Y.; Grossman, W.; Bernstein, H.S.; et al. Sca-1+ cardiosphere-derived cells are enriched for Isl1-expressing cardiac precursors and improve cardiac function after myocardial injury. PLoS ONE 2012, 7, e30329. [CrossRef]

40. Barile, L.; Messina, E.; Giacomello, A.; Marban, E. Endogenous cardiac stem cells. Prog. Cardiovasc. Dis. 2007, 50, 31-48. [CrossRef]

41. Beltrami, A.P.; Barlucchi, L.; Torella, D.; Baker, M.; Limana, F.; Chimenti, S.; Kasahara, H.; Rota, M.; Musso, E.; Urbanek, K.; et al. Adult cardiac stem cells are multipotent and support myocardial regeneration. Cell 2003, 114, 763-776. [CrossRef]

42. Choi, S.H.; Jung, S.Y.; Suh, W.; Baek, S.H.; Kwon, S.M. Establishment of Isolation and Expansion Protocols for Human Cardiac C-kit-Positive Progenitor Cells for Stem Cell Therapy. Transplant. Proc. 2013, 45, 420-426. [CrossRef]

43. Zhou, Y.; Pan, P.; Yao, L.; Su, M.; He, P.; Niu, N.; McNutt, M.A.; Gu, J. CD117-positive cells of the heart: Progenitor cells or mast cells? J. Histochem. Cytochem. 2010, 58, 309-316. [CrossRef]

44. Veinot, J.P.; Prichett-Pejic, W.; Song, J.; Waghray, G.; Parks, W.; Mesana, T.G.; Ruel, M. CD117-positive cells and mast cells in adult human cardiac valves-observations and implications for the creation of bioengineered grafts. Cardiovasc. Pathol. 2006, 15, 36-40. [CrossRef]

45. Sandstedt, J.; Jonsson, M.; Lindahl, A.; Jeppsson, A.; Asp, J. C-kit+ CD45- cells found in the adult human heart represent a population of endothelial progenitor cells. Basic Res. Cardiol. 2010, 105, 545-556. [CrossRef]

46. Di Meglio, F.; Castaldo, C.; Nurzynska, D.; Romano, V.; Miraglia, R.; Bancone, C.; Langella, G.; Vosa, C.; Montagnani, S. Epithelial-mesenchymal transition of epicardial mesothelium is a source of cardiac CD117-positive stem cells in adult human heart. J. Mol. Cell. Cardiol. 2010, 49, 719-727. [CrossRef]

47. Bronnum, H.; Andersen, D.C.; Schneider, M.; Nossent, A.Y.; Nielsen, S.B.; Sheikh, S.P. Islet-1 is a dual regulator of fibrogenic epithelial-to-mesenchymal transition in epicardial mesothelial cells. Exp. Cell Res. 2013, 319, 424-435. [CrossRef]

48. Min, K.W. Interstitial cells of Cajal (pICC) in the pancreas. J. Cell. Mol. Med. 2005, 9, 737-739. [CrossRef]

49. Manetti, M.; Guiducci, S.; Ruffo, M.; Rosa, I.; Faussone-Pellegrini, M.S.; Matucci-Cerinic, M.; Ibba-Manneschi, L. Evidence for progressive reduction and loss of telocytes in the dermal cellular network of systemic sclerosis. J. Cell. Mol. Med. 2013, 17, 482-496. [CrossRef]

50. Metzger, R.; Rolle, U.; Fiegel, H.C.; Franke, F.E.; Muenstedt, K.; Till, H. C-kit receptor in the human vas deferens: Distinction of mast cells, interstitial cells and interepithelial cells. Reproduction 2008, 135, 377-384. [CrossRef]

51. Armulik, A.; Genove, G.; Betsholtz, C. Pericytes: Developmental, physiological, and pathological perspectives, problems, and promises. Dev. Cell 2011, 21, 193-215. [CrossRef]

52. Smith, C.L.; Baek, S.T.; Sung, C.Y.; Tallquist, M.D. Epicardial-derived cell epithelial-to-mesenchymal transition and fate specification require PDGF receptor signaling. Circ. Res. 2011, 108, e15-e26. [CrossRef]

53. Rudat, C.; Norden, J.; Taketo, M.M.; Kispert, A. Epicardial function of canonical Wnt-, Hedgehog-, Fgfr1/2-, and Pdgfra-signalling. Cardiovasc. Res. 2013, 100, 411-421. [CrossRef]

54. Chong, J.J.; Reinecke, H.; Iwata, M.; Torok-Storb, B.; Stempien-Otero, A.; Murry, C.E. Progenitor cells identified by PDGFR-alpha expression in the developing and diseased human heart. Stem Cells Dev. 2013, 22, 1932-1943. [CrossRef]

55. Cretoiu, S.M.; Popescu, L.M. Telocytes revisited. Biomol. Concepts 2014, 5, 353-369. [CrossRef]

56. Manole, C.G.; Gherghiceanu, M.; Simionescu, O. Telocyte dynamics in psoriasis. J. Cell. Mol. Med. 2015, 19, 1504-1519. [CrossRef]

57. Wang, F.; Bei, Y.; Zhao, Y.; Song, Y.; Xiao, J.; Yang, C. Telocytes in pregnancy-induced physiological liver growth. Cell. Physiol. Biochem. 2015, 36, 250-258. [CrossRef]

58. Marini, M.; Mencucci, R.; Rosa, I.; Favuzza, E.; Guasti, D.; Ibba-Manneschi, L.; Manetti, M. Telocytes in normal and keratoconic human cornea: An immunohistochemical and transmission electron microscopy study. J. Cell. Mol. Med. 2017, 21, 3602-3611. [CrossRef]

59. Milia, A.F.; Ruffo, M.; Manetti, M.; Rosa, I.; Conte, D.; Fazi, M.; Messerini, L.; Ibba-Manneschi, L. Telocytes in Crohn's disease. J. Cell. Mol. Med. 2013, 17, 1525-1536. [CrossRef]

60. Vannucchi, M.G.; Traini, C.; Manetti, M.; Ibba-Manneschi, L.; Faussone-Pellegrini, M.S. Telocytes express PDGFRalpha in the human gastrointestinal tract. J. Cell. Mol. Med. 2013, 17, 1099-1108. [CrossRef] 
61. Zhou, Q.; Wei, L.; Zhong, C.; Fu, S.; Bei, Y.; Huica, R.I.; Wang, F.; Xiao, J. Cardiac telocytes are double positive for CD34/PDGFR-alpha. J. Cell. Mol. Med. 2015, 19, 2036-2042. [CrossRef]

62. Breiteneder-Geleff, S.; Matsui, K.; Soleiman, A.; Meraner, P.; Poczewski,H.; Kalt, R.; Schaffner, G.; Kerjaschki, D. Podoplanin, novel 43-kd membrane protein of glomerular epithelial cells, is down-regulated in puromycin nephrosis. Am. J. Pathol. 1997, 151, 1141-1152.

63. Al-Rawi, M.A.; Mansel, R.E.; Jiang, W.G. Molecular and cellular mechanisms of lymphangiogenesis. Eur. J. Surg. Oncol. 2005, 31, 117-121. [CrossRef]

64. Adamczyk, L.A.; Gordon, K.; Kholova, I.; Meijer-Jorna, L.B.; Telinius, N.; Gallagher, P.J.; van der Wal, A.C.; Baandrup, U. Lymph vessels: The forgotten second circulation in health and disease. Virchows Arch. 2016, 469, 3-17. [CrossRef]

65. Wetterwald, A.; Hoffstetter, W.; Cecchini, M.G.; Lanske, B.; Wagner, C.; Fleisch, H.; Atkinson, M. Characterization and cloning of the E11 antigen, a marker expressed by rat osteoblasts and osteocytes. Bone 1996, 18, 125-132. [CrossRef]

66. Mahtab, E.A.; Wijffels, M.C.; Van Den Akker, N.M.; Hahurij, N.D.; Lie-Venema, H.; Wisse, L.J.; Deruiter, M.C.; Uhrin, P.; Zaujec, J.; Binder, B.R.; et al. Cardiac malformations and myocardial abnormalities in podoplanin knockout mouse embryos: Correlation with abnormal epicardial development. Dev. Dyn. 2008, 237, 847-857. [CrossRef]

67. Sawa, Y. New trends in the study of podoplanin as a cell morphological regulator. Jpn. Dent. Sci. Rev. 2010, 46, 165-172. [CrossRef]

68. Astarita, J.L.; Acton, S.E.; Turley, S.J. Podoplanin: Emerging functions in development, the immune system, and cancer. Front. Immunol. 2012, 3, 283. [CrossRef]

69. Karunamuni, G.; Yang, K.; Doughman, Y.Q.; Wikenheiser, J.; Bader, D.; Barnett, J.; Austin, A.; Parsons-Wingerter, P.; Watanabe, M. Expression of lymphatic markers during avian and mouse cardiogenesis. Anat. Rec. 2010, 293, 259-270. [CrossRef]

70. Manetti, M.; Rosa, I.; Messerini, L.; Guiducci, S.; Matucci-Cerinic, M.; Ibba-Manneschi, L. A loss of telocytes accompanies fibrosis of multiple organs in systemic sclerosis. J. Cell. Mol. Med. 2014, 18, 253-262. [CrossRef]

71. Benias, P.C.; Wells, R.G.; Sackey-Aboagye, B.; Klavan, H.; Reidy, J.; Buonocore, D.; Miranda, M.; Kornacki, S.; Wayne, M.; Carr-Locke, D.L.; et al. Structure and Distribution of an Unrecognized Interstitium in Human Tissues. Sci. Rep. 2018, 8, 4947. [CrossRef] [PubMed]

72. Kholova, I.; Dragneva, G.; Cermakova, P.; Laidinen, S.; Kaskenpaa, N.; Hazes, T.; Cermakova, E.; Steiner, I.; Yla-Herttuala, S. Lymphatic vasculature is increased in heart valves, ischaemic and inflamed hearts and in cholesterol-rich and calcified atherosclerotic lesions. Eur. J. Clin. Investig. 2011, 41, 487-497. [CrossRef] [PubMed]

73. Simeone, P.; Trerotola, M.; Franck, J.; Cardon, T.; Marchisio, M.; Fournier, I.; Salzet, M.; Maffia, M.; Vergara, D. The multiverse nature of epithelial to mesenchymal transition. Semin. Cancer Biol. 2018. [CrossRef] [PubMed]

74. Smits, A.M.; Dronkers, E.; Goumans, M.J. The epicardium as a source of multipotent adult cardiac progenitor cells: Their origin, role and fate. Pharmacol. Res. 2018, 127, 129-140. [CrossRef]

75. Moerkamp, A.T.; Lodder, K.; van Herwaarden, T.; Dronkers, E.; Dingenouts, C.K.; Tengstrom, F.C.; van Brakel, T.J.; Goumans, M.J.; Smits, A.M. Human fetal and adult epicardial-derived cells: A novel model to study their activation. Stem Cell Res. Ther. 2016, 7, 174. [CrossRef] [PubMed]

76. Van Tuyn, J.; Atsma, D.E.; Winter, E.M.; van der Velde-van Dijke, I.; Pijnappels, D.A.; Bax, N.A.; Knaan-Shanzer, S.; Gittenberger-de Groot, A.C.; Poelmann, R.E.; van der Laarse, A.; et al. Epicardial cells of human adults can undergo an epithelial-to-mesenchymal transition and obtain characteristics of smooth muscle cells in vitro. Stem Cells 2007, 25, 271-278. [CrossRef] [PubMed]

77. Gittenberger-de Groot, A.C.; Winter, E.M.; Poelmann, R.E. Epicardium-derived cells (EPDCs) in development, cardiac disease and repair of ischemia. J. Cell. Mol. Med. 2010, 14, 1056-1060. [CrossRef] [PubMed]

78. Bax, N.A.; van Oorschot, A.A.; Maas, S.; Braun, J.; van Tuyn, J.; de Vries, A.A.; Groot, A.C.; Goumans, M.J. In vitro epithelial-to-mesenchymal transformation in human adult epicardial cells is regulated by TGFbeta-signaling and WT1. Basic Res. Cardiol. 2011, 106, 829-847. [CrossRef]

79. Risebro, C.A.; Vieira, J.M.; Klotz, L.; Riley, P.R. Characterisation of the human embryonic and foetal epicardium during heart development. Development 2015, 142, 3630-3636. [CrossRef] 
80. Viragh, S.; Gittenberger-de Groot, A.C.; Poelmann, R.E.; Kalman, F. Early development of quail heart epicardium and associated vascular and glandular structures. Anat. Embryol. 1993, 188, 381-393. [CrossRef] [PubMed]

81. Vrancken Peeters, M.P.; Mentink, M.M.; Poelmann, R.E.; Gittenberger-de Groot, A.C. Cytokeratins as a marker for epicardial formation in the quail embryo. Anat. Embryol. 1995, 191, 503-508. [PubMed]

82. Manta, L.; Rusu, M.C.; Pop, F. What podoplanin tells us about cells with telopodes. Ann. Anat. 2018, 218, 124-128. [CrossRef] [PubMed]

83. Liu, X.N.; Wang, S.; Yang, Q.; Wang, Y.J.; Chen, D.X.; Zhu, X.X. ESC reverses epithelial mesenchymal transition induced by transforming growth factor-beta via inhibition of Smad signal pathway in HepG2 liver cancer cells. Cancer Cell Int. 2015, 15, 114. [CrossRef] [PubMed]

84. Tian, H.; Xu, J.Y.; Tian, Y.; Cao, Y.; Lian, C.; Ou, Q.; Wu, B.; Jin, C.; Gao, F.; Wang, J.; et al. A cell culture condition that induces the mesenchymal-epithelial transition of dedifferentiated porcine retinal pigment epithelial cells. Exp. Eye Res. 2018, 177, 160-172. [CrossRef] [PubMed]

85. Stark, K.; Vainio, S.; Vassileva, G.; McMahon, A.P. Epithelial transformation of metanephric mesenchyme in the developing kidney regulated by Wnt-4. Nature 1994, 372, 679-683. [CrossRef]

86. Kispert, A.; Vainio, S.; McMahon, A.P. Wnt-4 is a mesenchymal signal for epithelial transformation of metanephric mesenchyme in the developing kidney. Development 1998, 125, 4225-4234.

87. Gessert, S.; Kuhl, M. The multiple phases and faces of wnt signaling during cardiac differentiation and development. Circ. Res. 2010, 107, 186-199. [CrossRef]

88. Merki, E.; Zamora, M.; Raya, A.; Kawakami, Y.; Wang, J.; Zhang, X.; Burch, J.; Kubalak, S.W.; Kaliman, P.; Izpisua Belmonte, J.C.; et al. Epicardial retinoid $X$ receptor alpha is required for myocardial growth and coronary artery formation. Proc. Natl. Acad. Sci. USA 2005, 102, 18455-18460. [CrossRef]

89. Compton, L.A.; Potash, D.A.; Mundell, N.A.; Barnett, J.V. Transforming growth factor-beta induces loss of epithelial character and smooth muscle cell differentiation in epicardial cells. Dev. Dyn. 2006, 235, 82-93. [CrossRef]

(C) 2019 by the authors. Licensee MDPI, Basel, Switzerland. This article is an open access article distributed under the terms and conditions of the Creative Commons Attribution (CC BY) license (http://creativecommons.org/licenses/by/4.0/). 